\title{
THE EFFECT OF MIXING MODES ON BIOHYDROGEN YIELD AND SPATIAL PH GRADIENT AT DARK FERMENTATION OF SOLID FOOD WASTE
}

\author{
Hanna Tashyreva, Oleksandr Tashyrev, Vira Govorukha, Olesya Havryliuk
}

\begin{abstract}
Dark fermentation of multicomponent solid food waste by soil hydrogen-producing bacterial community was studied in horizontal batch reactor under different mechanical mixing modes; speed of mixing (rpm) and frequency of mixing (duration mixing and pause) were selected as target for optimization. Addition of $\mathrm{pH}$ indicator bromothymol blue to the culture liquid allowed to study patterns of formation of acidification zones in solid/liquid/gaseous fermentation system. It was detected that mixing speed can contribute to sustainable maintenance of optimal $\mathrm{pH}$ values and prevent formation of spatial $\mathrm{pH}$ gradient. Adjusting of mixing and pause duration resulted in significant decrease of digestion cycle and increase in volumetric hydrogen production rate. Established optimal mixing mode $24 \mathrm{rpm}, 10 \mathrm{~min}$ of mixing/20 min of pause provided biohydrogen yield $123 \mathrm{~L}_{\mathrm{H} 2} \mathrm{~kg}^{-1} \mathrm{TS}_{\text {added }}$ and reduction in the concentration of total suspended solids from 70 to $0.75 \mathrm{~g} / \mathrm{L}$ in 4 days.
\end{abstract}

Key words: dark fermentation, mixing, biohydrogen, spatial pH-gradient, food waste, suspended solids

\section{INTRODUCTION}

Multi-component solid food waste is the most abundant type of food waste [1-3] and it is only natural that many researchers suggest using it as a substrate for dark fermentation biohydrogen production [4]. Over the past decade, studies were mostly focused on increasing the efficiency of biohydrogen yield in an attempt to reach values of theoretical calculations $4 \mathrm{mmol} \mathrm{H}_{2}$ per mmol of hexose [4-5]. However, inherent characteristics of multi-component solid food waste are often not suitable to provide high hydrogen output and develop cost-effective industrial technology. First of all, it has lower carbohydrate content compared to sugar-containing waste waters. Use of sucrose or glucose-containing wastes or synthetic water as a substrate can result hydrogen yield up to 3.5 mmol $\mathrm{H}_{2}$ [6], while for municipal food waste, the average yield is in range 1.6-2.2 $\mathrm{mmol} \mathrm{H}_{2}$ [5]. Additional disadvantage is loss of carbohydrates necessary for biohydrogen production due to uncontrolled consumption of nutrients by waste microflora during its collection, storage and transportation.

Meanwhile, hydrogen production and waste decomposition is the same process of disruption of natural polymers (cellulose, starch and proteins) [1]. Therefore, in the last few years the vision of application of hydrogen dark fermentation process have been changed and started to be considered as a good alternative for food waste recycling [7-8]. This approach creates additional value for the process and makes it promising for industrial application.

In the specified context, providing conditions for rapid waste decomposition is crucial. Nutrients of solid food waste are less available to hydrogen-producing microorganisms compared to glucose-containing industrial waste waters [9-10]. To increase the availability, solid waste is usually grinded to obtain highly dispersed suspension of particles, or so-called pulp, which is used for hydrogen fermentation [1113]. However, studies of optimal fermentation conditions show that higher hydrogen yield and efficient carbon conversion occur at lower content of total solids [14]. Hydrogen fermentation at high content of small particles results in high rate of decomposition of waste polymers resulting in rapid production of an excess of volatile fatty acids (VFA), extremely sharp decrease in $\mathrm{pH}$ value, followed by metabolic shift to solvent production and inhibition of hydrogen-producing bacteria [15]. Alternative approach to solid waste treatment could be based on using bigger particles to control access to the substrate and acidification process. Moreno-Andare [14] showed that adjusting of the particle size can be an efficient tool that will provide sustainable fermentation and improve hydrogen yield. Depending on the particle size, optimal content of solids may vary from 5 to $120 \mathrm{~g} \mathrm{TS}_{0} / \mathrm{L}$. An increase in the particle size makes possible to reduce the inhibitory effect observed at high amount of total solids. The applied positive consequence of this result is reduction in water consumption for fermentation process.

At the same time, the use of solid particles changes the basic principles of fermentation process. In the case of soluble carbohydratecontaining waste water, the fermentation process happens in the liquid phase as well as on the surface of granular sludge commonly used as a source of hydrogen-producing bacteria and additional substrate for co-digestion [16]. When 
using solid food waste, the process takes place in non-homogenous 3-phase solid/liquid/gaseous system [8] on the surface of solid particles. Under these conditions, acidification process occurs not equally in the whole reactor volume, but mainly on the surface of waste particles. Thus, efficient mass transfer with rinsing of acidic metabolites from the surface of waste particles is extremely important to maintain optimal fermentation conditions and provide high activity of $\mathrm{H}_{2}$-producing bacteria.

Analysis of numerous studies shows that $\mathrm{pH}$ value is the most important parameter influencing biohydrogen production $[4,8,15]$. During dark fermentation of solid waste, the suitable mixing might play a key role in maintaining optimal $\mathrm{pH}$ values and avoiding formation of $\mathrm{pH}$ gradients in a reactor. However, according to the latest reviews, mixing effect was not in focus of biohydrogen studies and the literature only addresses the effect of mixing on metanogenic bacteria [8].

This study is focused on the effect of mixing on maintenance of optimal $\mathrm{pH}$ values for biohydrogenproducing bacterial community and the initial stage of food waste decomposition, namely degradation of solid particles. Such key parameters as speed of mixing (rpm) and frequency of mixing (duration mixing and pause) were selected as target for optimization. Additional goal was to study spatial $\mathrm{pH}$ gradient in liquid/solid system during fermentation process and asses its effect on waste decomposition.

\section{MATERIALS AND METHODS}

\section{Food waste feedstock and microbial inoculum}

Synthetic food waste, consisting of components typical for Ukrainian culinary waste, was used in this study. Mixture included potato peels (50\%) and 5\% for each of the following components - chicken, tomatoes, cucumbers, zucchini, cabbage, carrots, apples, greenery, pasta and bread. All ingredients except pasta and bread were added both cooked and raw in equal proportion of $1: 1$. Waste was grinded to particle size of approximately $10-15 \mathrm{~mm}$ and used as the feedstock after pasteurization $\left(5 \mathrm{~min}, 90^{\circ} \mathrm{C}\right)$. Moisture and Total Solids (TS) content was determined by oven dry method, $100 \mathrm{~g}$ of grinded waste mixture was dried in conventional heat oven at $105{ }^{\circ} \mathrm{C}$ up to constant weight [17]. Results showed average moisture content of $77 \%$ and total solids of $235 \mathrm{~g} / \mathrm{kg}$ of raw waste mixture. $100 \mathrm{~g}$ of soil were mixed with the same amount of water, boiled for $30 \mathrm{~min}$ at $100^{\circ} \mathrm{C}$ to obtain mixed community of spore-forming aerobic and anaerobic hydrogen-producing bacteria, and then used as seed inoculum for combined dark hydrogen fermentation and anaerobic digestion.

\section{Batch reactor design}

Experiments were carried out in self-designed horizontal cylinder-shaped batch reactor with general operating volume of $20 \mathrm{~L}$ (Fig 1.).

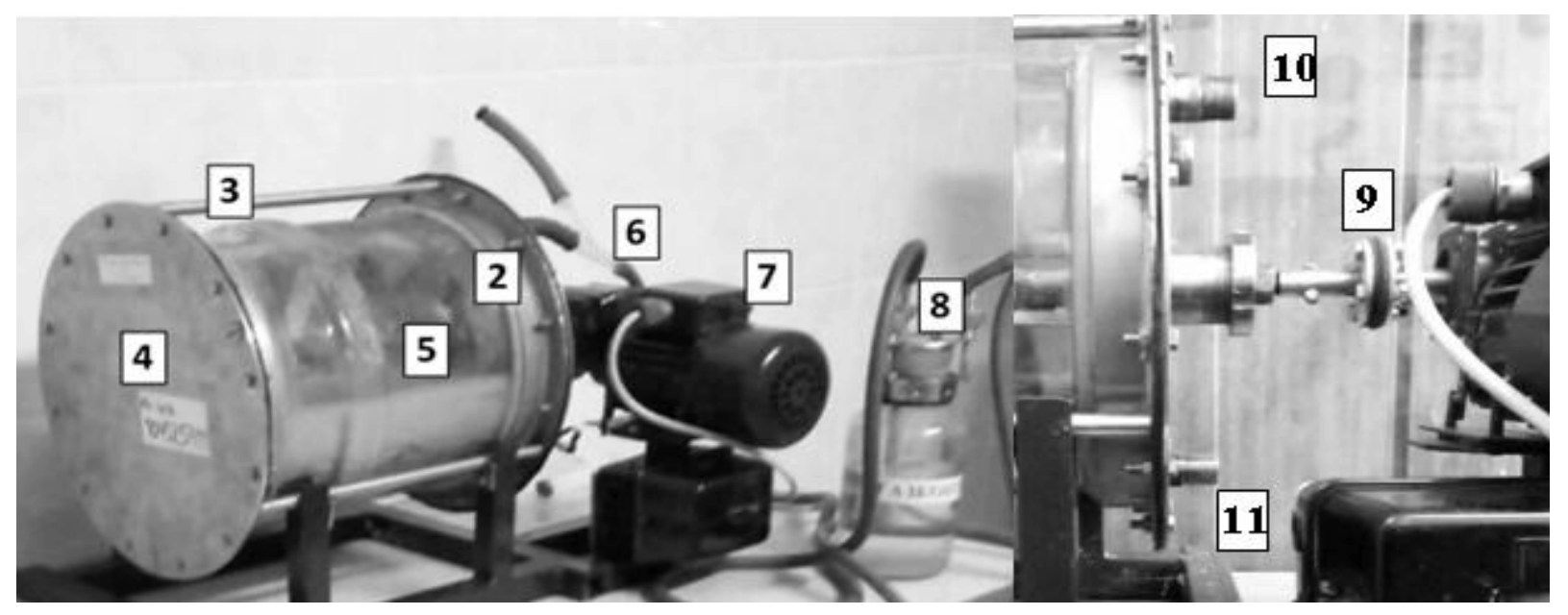

Fig. 1. Horizontal batch reactor

Working chamber of the reactor (1) was manufactured from transparent plastic to observe spatial distribution of solid particles at different mixing modes. Side construction of the reactor consisted of clamping rings (flanges) (2) built inside the plastic cylinder which was tightly attached to circle-shaped 
stainless steel plates (4) by clamping bolts (3), forming altogether reactor side surfaces. Mechanical mixing was provided by horizontal kernel with three paddles (5) built in the middle along the working chamber. Mixer was connected to the drive shaft (6) consistently attached to the electrical motor (180W) with speed reducer (7), through the gland (9). The reactor was connected by hydrogenimpenetrable elastic hoses with gas-controller (8) and water-filled plastic gasholder (volume $120 \mathrm{~L}$ ) marked with graduated scale for gas volume measuring. Gas-controller was used for visual monitoring of gas synthesis intensity. The gas volume was measured by volume of water pushed out from the gasholder under the pressure into additional container. Top (10) and bottom (11) sockets were used for gas and culture liquid sampling as well as adding compounds for $\mathrm{pH}$ maintenance.

\section{Fermentation set-up and mixing modes}

For each fermentation cycle, $2 \mathrm{~kg}$ of food waste mixture, $6 \mathrm{~L}$ of boiled tap water, bacterial inoculum and $0.1 \%$ water solution of $\mathrm{pH}$ indicator bromothymol blue were added into the reactor chamber up to total liquid volume of around 7 L. $50 \%$ of air head space in the reactor was left without replacing it with inert gas. Oxygen consumption and establishment of anaerobic conditions were additional criteria to study metabolic activity of bacterial communities. Initial concentration of the total solids $\left(\mathrm{TS}_{0}\right)$ was on average $70 \mathrm{~g} / \mathrm{L} ; \mathrm{pH}$ was adjusted by $\mathrm{NaHCO}_{3}$ up to initial values in a range of 6.8-7.2. Fermentation was carried out at $30^{\circ} \mathrm{C}$ during 7 days. Study of optimal mixing conditions was conducted in two stages. At the first stage, the optimal speed of mixing was determined. For this purpose, fermentations with 3 different speed of mixing were carried out - 1) $12 \mathrm{rpm}$; 2) $24 \mathrm{rpm}$; 3$) 48 \mathrm{rpm}$. At the second stage, the following two modes were applied to study the effect of mixing and pause ratio under optimal speed of mixing: 1) $5 \mathrm{~min}$ of mixing / 1 hour of pause and 2) $10 \mathrm{~min}$ of mixing / $20 \mathrm{~min}$ of pause. All experiments were carried out in duplicates; fermentation cycle without mixing was used as a control.

\section{Measurement and control of operating conditions}

Four parameters of the gas and liquid phase were measured to monitor digestion process and biohydrogen production. These were gas volume, gas composition, $\mathrm{pH}$ value and oxidation-reduction potential (ORP). During the first two days of fermentation cycle all the parameters were measured every 3 hours; starting from the third day - once in 6 hours. Samples of culture liquid were collected using socket at the bottom of the reactor. The $\mathrm{pH}$ and ORP values were measured using portable $\mathrm{pH}$ meter-millivolt meter "pH-150 MA". ORP was measured by platinum electrode EPV-1; silver chloride electrode EVL-1M3 served as the reference electrode. Spatial $\mathrm{pH}$ gradient in the reactor was detected and evaluated by visual observations in changes of $\mathrm{pH}$ indicator bromothymol blue $(\mathrm{pH}>7$ - blue, $\mathrm{pH}=7$ - green, $5<\mathrm{pH}<6-$ yellow, and $\mathrm{pH}$ $<5$ - orange-yellow). Maintenance of optimal $\mathrm{pH}$ value from 6.8 to 7 was carried out by concentrated $\mathrm{NaHCO}_{3}$ solution. Average $\mathrm{pH}$ value of cultural liquid was measured by porous glass electrode ESK10603/4 before and after adjustment.

Gas volume was quantified by the amount of water displacement in the gas holder. Samples for gas analysis were collected from headspace sampler using $2.5 \mathrm{ml}$ plastic sterile syringes with rubber gasket («Bayer») and then immediately transferred for gas chromatographic analysis. Biogas composition (hydrogen, carbon dioxide, methane) and residual amount of nitrogen and oxygen were determined by the standard method using gas chromatograph LHM-8-MD. The chromatograph was equipped with thermal conductivity detector and two stainless-steel columns packed 13X (NaX) Porapak-Q carrier with argon as carrier gas - first (I $-3 \mathrm{~m} / 3 \mathrm{~mm}$ ) for $\mathrm{H}_{2}, \mathrm{O}_{2}, \mathrm{~N}_{2}$ and $\mathrm{CH}_{4}$ analysis, second (II $-2 \mathrm{~m} / 3 \mathrm{~mm}$ ) - for $\mathrm{CO}_{2}$ analysis. The column and detector temperature was $+60^{\circ} \mathrm{C}$; evaporator temperature was $+75^{\circ} \mathrm{C}$; detector current - $50 \mathrm{~mA}$; gas flow rate was $30 \mathrm{~cm}^{3} / \mathrm{min}$. Composition of the biogas was calculated by the peak areas of each component.

\section{Assessment efficiency of mixing modes}

The overall conclusion concerning efficiency of mixing modes was made based on three groups of criteria:

1) Ability to provide optimal fermentation conditions - kinetics of $\mathrm{pH}$ and ORP values during fermentation cycle and characteristics of $\mathrm{pH}$ gradient in the reactor;

2) Effect on biogas yield and composition, which was calculated as biogas and biohydrogen yield (L/batch fermentation), biohydrogen yield $\mathrm{L}_{\mathrm{H} 2} \mathrm{~kg}^{-1}$ $\mathrm{TS}_{\text {added }}$ and volumetric hydrogen production rate (VHPR) $\mathrm{L}_{\mathrm{H} 2} \mathrm{~kg}^{-1} \mathrm{TS}_{\text {added }} \mathrm{h}^{-1}$.

3) The efficiency of solid particles decomposition assessed by final concentration of total suspended 
solid $\left(\mathrm{TSS}_{\mathrm{F}}\right)$, ratio of initial and final concentration of solids $\left(\mathrm{TS}_{0} / \mathrm{TSS}_{\mathrm{F}}\right)$ and duration of digestion cycle. Duration of fermentation cycle was determined by parameters of metabolic activity of the microbial community. Increased ORP value, stabilization of $\mathrm{pH}$ level and significant reduction or termination of gas production were indicators for the end of fermentation process. The amount of total solids and total suspended solids was determined according to the Standard Methods [17]. Reduction in the amount of solid waste particles after fermentation was expressed as Decomposition index $\left(I_{D}\right)$

$$
I_{D}=100 \%-\frac{\mathrm{m} 2}{\mathrm{~m} 1} \times 100 \% \text {, }
$$

where $\mathrm{m}_{2}$ - weight of total suspended solids after fermentation $(\mathrm{g})$ and $\mathrm{m}_{1}$ - weight of total solids before fermentation $(\mathrm{g}) ; \frac{\mathrm{m} 2}{\mathrm{~m} 1} \times 100 \%$ comprises amount of unfermented solid residues after the end of fermentation cycle.

\section{RESULTS AND DISCUSSION}

Effect of the speed of mixing on formation of spatial $\mathrm{pH}$ gradient

Distribution of waste particles in the reactor volume and formation of spatial $\mathrm{pH}$ gradient were studied under three different speeds of mixing: 12 , 24 and $48 \mathrm{rpm}$. After 5 minutes of continuous mixing sedimentation of food particles and changes of $\mathrm{pH}$ indicator colour were observed through transparent reactor chamber during 2 hours. Specified changes were detected in the most active fermentation phase between $10^{\text {th }}$ and $20^{\text {th }}$ hour of batch incubation, when processes of polymer decomposition, medium acidification and hydrogen production are the most intensive. $\mathrm{pH}$ indicator bromothymol blue, added to culture liquid in each experiment, is highly sensitive to slight $\mathrm{pH}$ changes and shows useful range at relatively neutral values from 7.5 to 5.5 providing color gradient from intense blue to hot and significant visibly of differences in shades of yellow and green colors even at 0.2 -unit $\mathrm{pH}$ shift. Additionally, the indicator at concentration of $0.1 \%$ is non-toxic for hydrogen-producing bacteria and does not affect their activity. Use of bromothymol for dark hydrogen fermentation blue gives an opportunity to obtain advanced knowledge about formation of $\mathrm{pH}$ gradient (including rate and intensity) on the border of solid/liquid phases without breaking the natural fermentation processes in the reactor.
For all studied rotation speeds, the reactor and mixer geometry provided equal distribution of waste particles during mixing. During 10-25 minutes after mixing particles gradually settled at the bottom of the reactor forming loose layer which initially occupied approximately half of the liquid phase. Under $12 \mathrm{rpm}$ mode solid particles started segregated into two layers in 1 hour after mixing. The first layer was formedl by particles settled at the reactor bottom; the second - by waste particles saturated with gas bubbles which floated up on the surface of cultural liquid. During the second hour the colour of bromothymol blue changed from intense green to yellow in both layers of solid particles remaining light green cultural liquid between them. This indicates formation of two acidification zones with $\mathrm{pH}$ value 5.5 or lower. Taking into account that previously detected $\mathrm{pH}$ optimum for hydrogen-producing soil microbial community was 6.8-7.0, the use of mixing speed 12 rpm results in formation of unfavourable conditions in around 1.5 hour after mixing.

After mixing under $24 \mathrm{rpm}$ mode some of waste particles settled at the bottom and some floated in the culture liquid in the middle of the reactor due to enrichment of particles with gas bubbles. Gas saturated particles did not reach the surface and distributed along reactor volume. Observation of $\mathrm{pH}$ indicator colour change showed gradual shift from dark green to yellowgreen during 1 hour that indicates smooth VFA distribution in the reactor volume and the absence of acidification zones around waste particles.

Application of mixing speed of $48 \mathrm{rpm}$ resulted in mechanical deterioration of partly digested waste particles after 15 hours of incubation. Small particles settled down at the reactor bottom forming thick layer of gel-like structure. Bromothymol blue showed the colour chart from dark green at the reactor top to hot yellow at the bottom indicating $\mathrm{pH}$ gradient in a range approximately from 7.0 to 5.0. Additional negative effect was medium foaming which disrupted sustainable reactor operation by hindering of gas transfer out of the reactor chamber to the gas holder. To obtain clear images of acidification zones, experiments were additionally set in serum bottles (Fig. 2)

Thus, the optimal speed of mixing in the horizontal reactor was established to be $24 \mathrm{rpm}$. It provided the most equal distribution of waste particles in the reactor volume did not affect particle structure and prevented formation of acidification zones. 

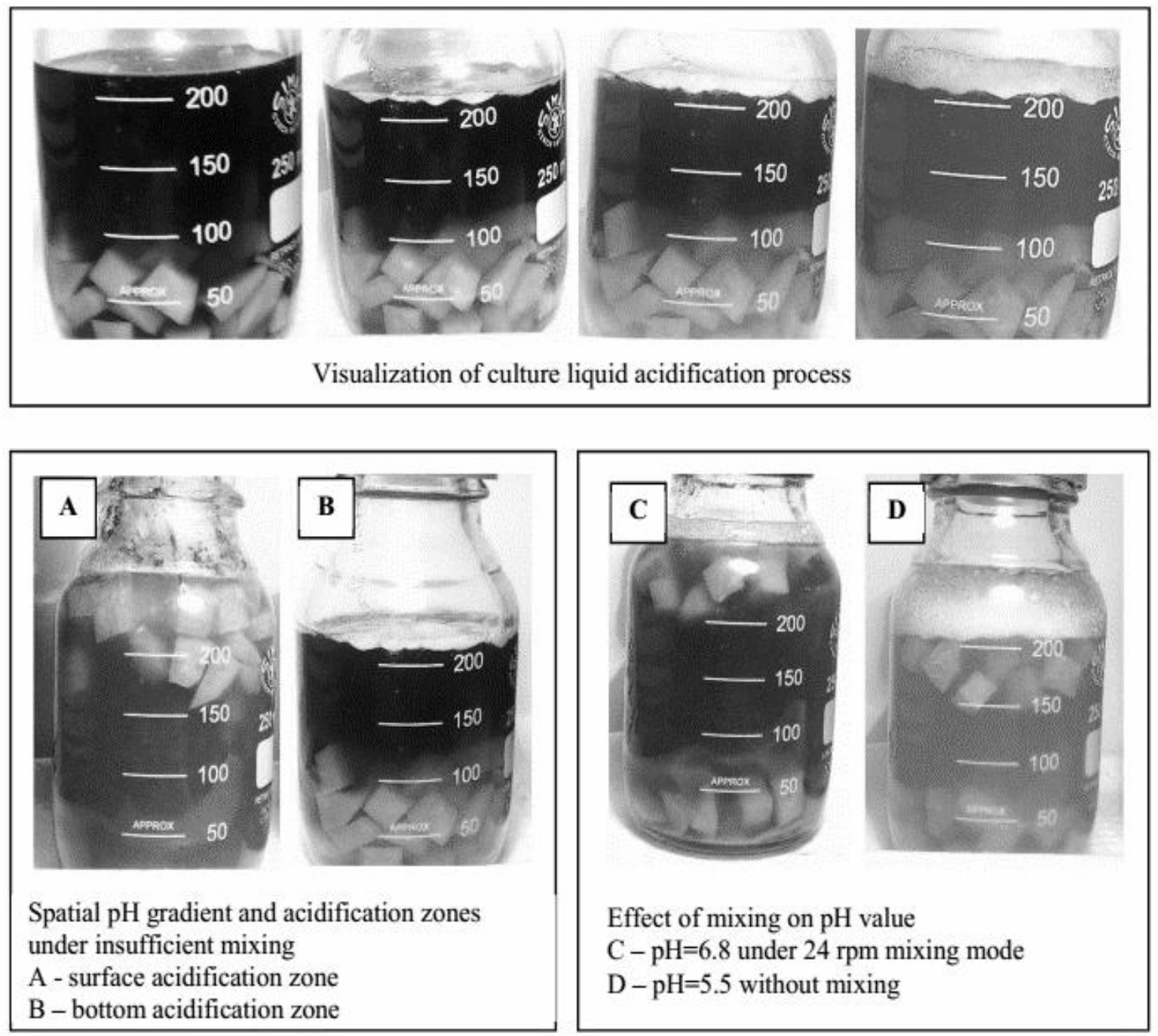

Fig.2 Application of bromothymol blue indicator for discovery of spatial $\mathrm{pH}$ gradient dark hydrogen fermentation of solid food waste (dark areas - green color, $\mathrm{pH} 6.8$; light areas - yellow color $\mathrm{pH} \leq 5.5$ ), for color images, please download e-version from Journal website

Although the speed of mixing of $24 \mathrm{rpm}$ is optimal for particular microbial community, size of particles, reactor design and other parameters, the results of these experiments allow assuming that the speed of mixing might effect at least three important processes during dark hydrogen fermentation. Faster acidification process around waste particles at low rotation speed proves that mixing might contribute to VFA rinsing from the particle surface and support suitable $\mathrm{pH}$ values. Intense gas saturation of waste particles testifies that bacterial cells are absorbed on the particle surface and excrete liquid and gaseous metabolites inside the outer layer of partly fermented solid particles. Decrease in gas saturation at higher rotation speed indicates that mixing may affect hydrogen concentration and pressure in local fermentation microenvironments and also contribute to the control of bacterial cell adhesion on waste surface. High speed of mixing resulted in deterioration of waste particles followed by intense acidification. Relying on this fact, it is possible to assume that suitable rotation speed contributes to control of particle size during fermentation. Hydrogen and soluble metabolite concentration in culture medium are reported to be the most important inhibitors of fermentation process [15], while high content of total solids causes solvent production, which also suppresses hydrogen-producing bacteria. Adjusting of mixing speed may reduce aforementioned negative effects as well as allows reaching high values 
of organic loading rate without decreasing of bacterial metabolic activity.

Analysis of temporal profiles of dark hydrogen fermentation under different mixing modes

Dynamics of hydrogen fermentation has been studied during 170 hours ( 7 days) under two mixing modes: 1) 5 min mixing / 1-hour pause; 2) $10 \mathrm{~min}$ mixing / 20 min pause; for both modes mixing speed was $24 \mathrm{rpm}$ detected as optimal at the previous stage. $\mathrm{pH}$ was adjusted by $\mathrm{NaHCO}_{3}$ solution starting from establishment of anaerobic conditions in the reactor chamber. The results were compared with control fermentation without mixing and $\mathrm{pH}$ adjusting. Temporal profiles of physicochemical parameters and gas production are shown on Fig.3.

In all experiments the ORP value reduced from $+250 \ldots+320 \mathrm{mV}$ to $-200 \ldots-230 \mathrm{mV}$ during the first 8-12 hours of incubation independently of mixing modes. It indicates that pre-treated soil microbial community contains aerobic and anaerobic bacteria that are able to establish strictly anaerobic conditions which are necessary for biogydrogen production [18] without water deoxygenation or replacement reactor headspace with inert gas. At this stage mixing did not have any noticeable impact on ORP value; however, it affected $\mathrm{pH}$ starting from the first hours of fermentation. For the control fermentation without mixing, $\mathrm{pH}$ value decreased by less than one unit from 6.9 to 6.0 after 9 hours of incubation while for both mixing modes it decreased from 7.2-7.1 to 5.6-5.5. This difference shows impact of mixing on substrate consumption even at the early stages of microbial community development and without $\mathrm{pH}$ adjustment.

Starting from the $10^{\text {th }}$ hour, when anaerobic conditions were set up, the most active stage of hydrogen fermentation was observed in all experiments until the end of the second day (48 hours of incubation). This was detected by strong acidification of liquid phase and powerful biogas production. Visual observation of solid waste distribution showed splitting of particles into thick surface and bottom layers, and changing $\mathrm{pH}$ indicator color to hot yellow $(\mathrm{pH} \leq 5.5)$ in $30-40$ minutes under 5 min mixing / 1-hour pause mode. 10 min mixing / 20 min pause mode did not result in formation of acidification zones; the color of culture medium was the same yellow-green $(\mathrm{pH}=6.0-6.2)$ along reactor volume and waste particles were also equally distributed. $\mathrm{pH}$ measurements showed the average difference of 0.9 units before and after adjustment for the first mixing mode and 0.5 units for the second mode. The control experiment without mixing and $\mathrm{pH}$ adjustment showed $\mathrm{pH}$ stabilization at 5.5. Under these conditions, microbial community supported ORP at the value of $-150 \ldots-250 \mathrm{mV}$ and showed the highest biogas yield (10L) after 25 hours of fermentation.

According to observations of ORP and gas production dynamics, detected $\mathrm{pH}$ fluctuations significantly affected metabolic activity of the hydrogen-producing bacterial community. Under 1hour pause ORP value was between -200 and -350 $\mathrm{mV}$; ORP fluctuation coincided with a sharp decrease in $\mathrm{pH}$ value. Under 20-minute pause ORP value remained at the constant level of $-350 \mathrm{mV}$. For both mixing modes the peak of gas production was observed on the $22^{\text {nd }}$ hour of fermentation. Chromatographic analysis showed only presence $\mathrm{H}_{2}$ and $\mathrm{CO}_{2}$ in the gas mixture during digestion cycle, methane was not detected. However, the second mixing mode provided 3 times higher biogas yield (117 L) compared to the first one (43 L). Based on the obtained temporal profiles it is possible to assume that optimal $\mathrm{pH}$ level affects the sustainability of the microbial community functioning, namely in the ability to support constant ORP level. Sharp $\mathrm{pH}$ fluctuations also may reduce $\mathrm{NaHCO}_{3}$ buffering capacity and require more time for stabilization of $\mathrm{pH}$ value that negatively influences metabolic activity of the microbial community. Additionally, $\mathrm{NaHCO}_{3}$ excess can result in increase in total salinity of the liquid phase that also inhibits hydrogen-producing bacteria [15].

Starting from the third day of fermentation, $\mathrm{pH}$ values were stabilized at optimum level 6.8-7.0 for both mixing modes. Mixing resulted in mechanical deterioration of waste particles that was not observed before. It testifies that the major part of substrate consumption and waste decomposition occurred during the first two days. The biogas production significantly decreased compared to the first active phase and made around 10L/day. Hydrogen content in biogas was the highest at mixing mode 10 min mixing / 20 min pause $-40 \%$ during 40 hours. For mixing mode 5 min mixing / 1-hour pause, hydrogen content in gas mixture was around $30 \%$ from $40^{\text {th }}$ to $70^{\text {th }}$ hour of incubation. In control experiment, the highest hydrogen content was detected around $43 \%$, but low biogas yield (less than $3 \mathrm{~L} /$ day on average) made this amount extremely low compared to mixing modes. 

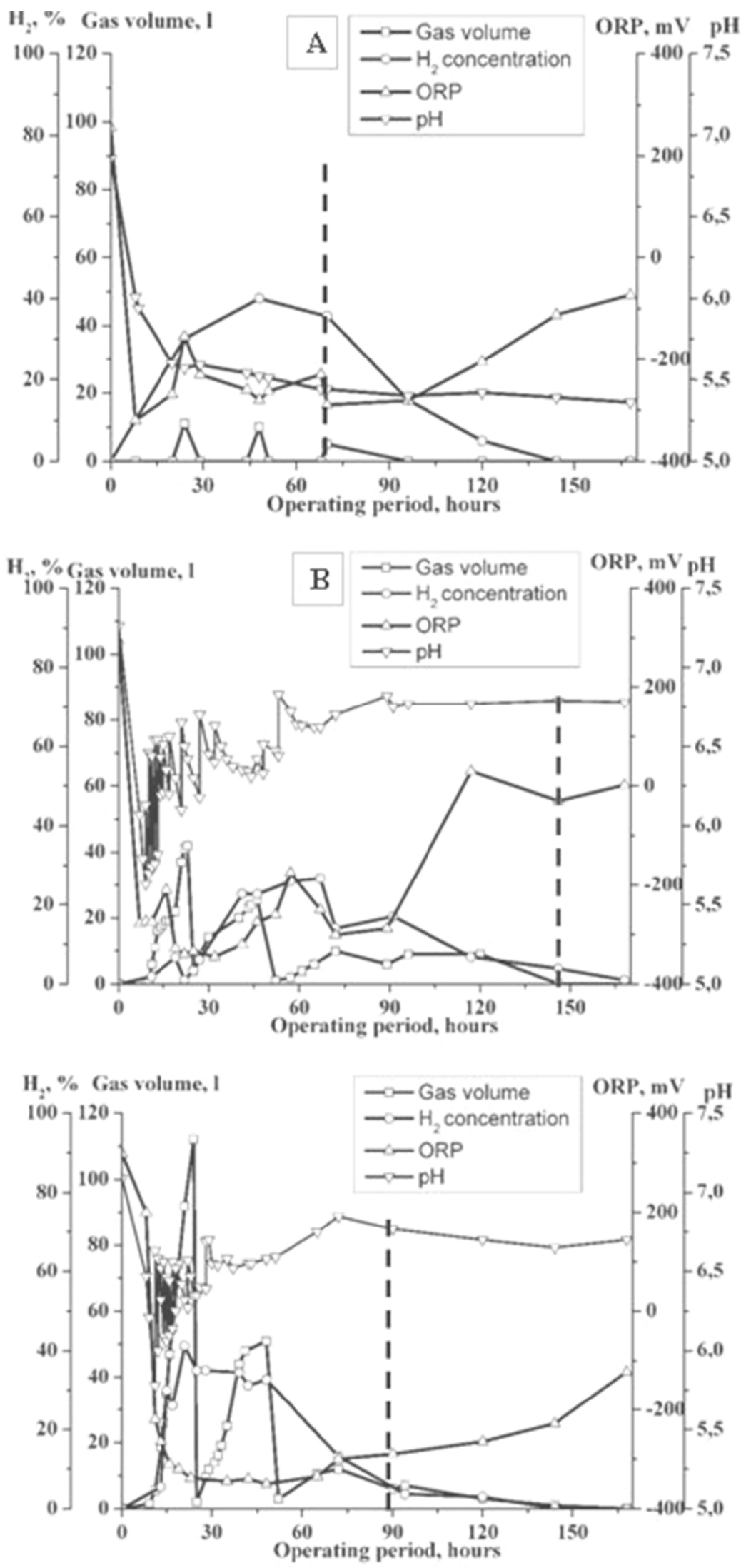

Fig 3. Dynamics of operation parameters and biogas production under different mixing modes A - control without mixing, B - 5 min mixing / 1 -hour pause, $\mathrm{C}-10$ min mixing / 20 min pause - _ - - Line indicates reduction of metabolic activity and the end of digestion cycle 
The effect of mixing modes on biohydrogen production and food waste decomposition Experiment results on decomposition of solid waste particles and biogas production are summarized in Table 1. Application of different mixing modes resulted in significant differences in biohydrogen yield, its production rate as well as in reduction of total amount of suspended solids. The same waste composition, organic loading rate and fermentation conditions provided accomplishment of digestion cycle after 140 hours under 5 min mixing / 1-hour pause mode and reduction of digestion duration 1.5 times up to 90 hours under 10 min mixing $/ 20 \mathrm{~min}$ pause mode.

Table 1. Efficiency of dark hydrogen fermentation under different mixing modes

\begin{tabular}{|c|c|c|c|}
\hline Fermentation parameters & Control & $\begin{array}{c}5 \text { min mixing / } \\
\text { 1-hour pause }\end{array}$ & $\begin{array}{c}10 \text { min mixing / } \\
20 \text { min pause }\end{array}$ \\
\hline \multicolumn{4}{|c|}{ Waste particles digestion parameters } \\
\hline Duration of digestion cycle, hours & $\mathrm{n} / \mathrm{a}$ & 140 & 90 \\
\hline TSS $_{\mathrm{F}}$ - TSS g/L after fermentation & 16.9 & 2.3 & 0.7 \\
\hline TS0/TSSF & 4.0 & 58.6 & 93.8 \\
\hline Decomposition index $I_{D}, \%$ & 76 & 96.7 & 99 \\
\hline \multicolumn{2}{|c|}{ Biogas yield parameters } \\
\hline Total biogas yield/cycle, L & 11 & 100 & 182 \\
\hline Total biohydrogen yield/cycle, L & 4.4 & 21 & 57 \\
\hline Biohydrogen yield $\mathrm{L}_{\mathrm{H} 2} \mathrm{~kg}^{-1} \mathrm{TS}$ added & 13.4 & 44.3 & 1.37 \\
\hline VHPR - LH2 $\mathrm{kg}-1 \mathrm{TSadded} \mathrm{h-1}$ & $\mathrm{n} / \mathrm{a}$ & 0.32 & \\
\hline
\end{tabular}

Finalization of digestion process was considered as termination of gas production, the absence of acidification during 3-4 hours and visible deterioration of waste particles. At the end of the fermentation cycle, unfermented residues included thin layer of detritus at the reactor bottom and small amount of lignocellulose peels or fibers which are normally not digested under mesophilic hydrogen fermentation [4]. The efficiency of waste decomposition was the highest under the second mixing mode - concentration of total suspended solids reduces 93.4 times from 70 to 0.75 $\mathrm{g} / \mathrm{L}$, the value of $I_{D}$ made $99 \%$ that indicates complete deterioration of solid particles. Application of $10 \mathrm{~min}$ mixing / $20 \mathrm{~min}$ pause mode also increased biohydrogen yield 2.9 times $\left(123 \mathrm{~L}_{\mathrm{H} 2} \mathrm{~kg}^{-1} \mathrm{TS}_{\text {added }}\right)$ compared to 5 min mixing / 1-hour pause mode (44 $\mathrm{L}_{\mathrm{H} 2} \mathrm{~kg}^{-1} \mathrm{TS}_{\text {added }}$ ). Additionally, intensification of mixing increased the value of VHPR 4.2 times due to shortening of the fermentation cycle.

\section{CONCLUSIONS}

The results testify that the same pattern of waste hydrogen fermentation occurs at different mixing modes, with $\mathrm{pH}$ adjustment and without it.
However, the mixing mode can affect metabolic activity of the hydrogen-producing microbial community and duration of digestion cycle. The development of the optimal mixing mode allows to avoid the formation of acidification zones during the dark hydrogen fermentation of solid multicomponent food waste as well as achieve high biohydrogen yield and efficient waste decomposition under high concentrations of total solids.

ACKNOWLEDGEMENTS: This study was financially supported by Comprehensive Program of Basic Research, NAS of Ukraine "Fundamental problems of hydrogen and renewable energy and fuel all technologies", Grant \# 2-16 "Development optimum mass transfer mode for horizontal batch reactor» and Joint Ukrainian-Indian collaborative project, DST India/Ministry of Science and Education of Ukraine M-82/2015 «Development of microbial technology of accelerated decomposition of multicomponent municipal food waste». 


\section{REFERENCES}

1. Urbaniec K., Bakker R.R., (Biomass residues as raw material for dark hydrogen fermentation - A review.), Int J Hydrogen Energy., Vol. 40, No 9, 2015, 3648-58.

2. Yasin NHM, Mumtaz T, Hassan M.A, Abd Rahman N., (Food waste and food processing waste for biohydrogen production: A review.), J Environ Manag., Vol. 130, 2013, 375-85.

3. Jiunn-Jyi Lay, Young-Joon Lee, Tatsuya Noike, (Feasibility of biological hydrogen production from organic fraction of municipal solid waste), Water Research, Vol. 33, No 11, 1999, 2579-2586, https://doi.org/10.1016/S0043-1354(98)00483-7.

4. Ghimire A., Frunzo L., Pirozzi F., Trably E., Escudie R., Lens PNL, Esposito G. (A review on dark fermentative biohydrogen production from organic biomass: Process parameters and use of byproducts.), Appl. Energy, Vol. 144, 2015, 73-95.

5. Bibi Shahine Firdaus Boodhun, Ackmez Mudhoo, Gopalakrishnan Kumar, Sang-Hyoun Kim, Chiu-Yue Lin, (Research perspectives on constraints, prospects and opportunities in biohydrogen production), Int J Hydrogen Energy, Available online 03 May 2017

https://doi.org/10.1016/j.ijhydene.2017.04.077.

6. Vivian Maria Carminato Blanco, Lucas Tadeu Fuess, Marcelo Zaiat, (Calcium dosing for the simultaneous control of biomass retention and the enhancement of fermentative biohydrogen production in an innovative fixed-film bioreactor), Int $\mathrm{J}$ Hydrogen Energy, Available online 18 March 2017, https://doi.org/10.1016/j.ijhydene.2017.02.180.

7. Shikha Dahiya, Omprakash Sarkar, Y.V. Swamy, S. Venkata Mohan, (Acidogenic fermentation of food waste for volatile fatty acid production with co-generation of biohydrogen), Bioresource Technology, Vol. 182, 2015, 103-113, https://doi.org/10.1016/j.biortech.2015.01.007.

8. Trad Z, Fontaine J-, Larroche C, Vial C., (Multiscale mixing analysis and modelling of biohydrogen production by dark fermentation), Renew Energy, Vol. 98, 2016, 264-82.

9. Wei Han, Min Ye, Ai Jun Zhu, Jin Gang Huang, Hong Ting Zhao, Yong Feng Li, (A combined bioprocess based on solid-state fermentation for dark fermentative hydrogen production from food waste), J.of Cleaner Production, Vol.112, No 5, 2016, 37443749, https://doi.org/10.1016/j.jclepro.2015.08.072.
10. Lihong Shen, David M. Bagley, Steven N. Liss, (Effect of organic loading rate on fermentative hydrogen production from continuous stirred tank and membrane bioreactors), Int J Hydrogen Energy, Vol. 34, No 9, 2009, 3689-3696

https://doi.org/10.1016/j.ijhydene.2009.03.006.

11. Arslan C, Sattar A, Changying J, Nasir A, Ali Mari I, Zia Bakht M., (Impact of $\mathrm{pH}$ management interval on biohydrogen production from organic fraction of municipal solid wastes by mesophilic thermophilic anaerobic codigestion), BioMed Res Int, 2015.

12. Cheng J, Ding L, Lin R, Yue L, Liu J, Zhou J, Cen K., (Fermentative biohydrogen and biomethane co-production from mixture of food waste and sewage sludge: Effects of physiochemical properties and mix ratios on fermentation performance), Appl Energy, Vol. 184, 2016,1-8.

13. Jaruwan Wongthanate, Kittibodee Chinnacotpong, (Optimal conditions for biological hydrogen production from food waste), Environmental Engineering Research, Vol.20, No 2, 2015,121-125. doi:https://doi.org/10.4491/eer.2013.104

14. Iván Moreno-Andrade, Germán Buitrón, (Evaluation of particle size and Initial concentration of total solids on Biohydrogen production from food waste), Fresenius Environmental Bulletin, Vol. 24, No 7, 2289-2295.

15. Bundhoo MAZ, Mohee R., (Inhibition of dark fermentative bio-hydrogen production: A review.), Int J Hydrogen Energy, Vol. 41, No 16, 2016, 6713-33.

16. Eduardo Dellosso Penteado, Carolina Zampol Lazaro, Isabel Kimiko Sakamoto, Marcelo Zaiat, (Influence of seed sludge and pretreatment method on hydrogen production in packed-bed anaerobic reactors), Int J Hydrogen Energy, Vol. 38, No 14, 2013, 6137-6145,

https://doi.org/10.1016/j.ijhydene.2013.01.067.

17. APHA, Standard Methods for the Examination of Water and Wastewaters, American Public Health Association, Washington D.C., 2012, $1496 \mathrm{p}$.

18. Jiaxiu Song, Dong An, Nanqi Ren, Yongming Zhang, Ying Chen, (Effects of $\mathrm{pH}$ and ORP on microbial ecology and kinetics for hydrogen production in continuously dark fermentation), Bioresource Technology, Vol. 102, No 23, 2011, 10875-10880, https://doi.org/10.1016/j.biortech.2011.09.024. 


\title{
ЕФЕКТ НА РЕЖИМИТЕ НА СМЕСВАНЕ ВЪРХУ ДОБИВА НА БИОВОДОРОД И ПРОСТРАНСТВЕНИЯ РН ГРАДИЕНТ ПРИ ФЕРМЕНТАЦИЯ НА ТЬМНО НА ТВЬРДИ ХРАНИТЕЛНИ ОТПАДЫЦИ
}

\author{
Ханна Таширева, Александр Таширев, Вира Говоруха, Олеся Хаврилюк
}

\begin{abstract}
Резюме: Ферментацията на тъмно на многокомпонентни твърди хранителни отпадъци от водород продуцираща бактериална общност, бе изследвана в хоризонтален реактор при различни режими на механично смесване; Скоростта на смесване (rpm) и честотата на смесване (продължителност на смесване и пауза) бяха избрани като цел за оптимизация. Добавянето на бромотимол синьо като $\mathrm{pH}$ индикатор към културалната течност позволява да се изследват проби от образуваните зони на подкиселяване в твърдата/течната/газообразната ферментационна система. Установено е, че скоростта на смесване може да допринесе за устойчиво поддържане на оптимални стойности на $\mathrm{pH}$ и да предотврати образуването на пространствен $\mathrm{pH}$ градиент. Регулирането на продължителността на смесването и паузата води до значително намаляване на цикъла на разграждане и увеличаване на обемното производство на водород. Установен е оптимален режим на смесване от $24 \mathrm{rpm}, 10$ мин смесване/20 мин пауза, който осигурява добив на биоводород от $123 \mathrm{~L}_{\mathrm{H} 2} \mathrm{~kg}-1 \mathrm{TS}_{\text {добавен }}$ и намалява концентрацията на общото суспендирано твьрдо вещество от 70 до $0.75 \mathrm{~g} / \mathrm{L}$ за 4 дни.
\end{abstract}

Ключови думи: ферментация на тъмно, смесване, биоводород, пространствен рН-градиент, хранителни отпадъци, суспендирани твърди вещества

\section{Principal investigator Hanna Tashyreva, PhD, Postdoc}

Center for Tropicalization, Center for Research Management and Innovation, National Defence University of Malaysia,

Address: Ground Floor, Research Management Complex, Camp Sungai Besi, 57000 Kuala Lumpur tel,: +60 3-9051 3400 ext 3085

Zabolotny Institute of Microbiology and Virology of the NAS of Ukraine, Department of Extremophilic Microorganism Biology, room 227

Address: Zabolotny str., 154, Kyiv, 03143, Ukraine

e-mail: anna.tashyreva@gmail.com, hanna.tashyreva@upnm.edu.my

\section{Principal investigator Prof. Oleksandr Tashyrev, Head of the Department}

Zabolotny Institute of Microbiology and Virology of the NAS of Ukraine, Department of Extremophilic Microorganism Biology, room 224

Address: Zabolotny str., 154, Kyiv, 03143, Ukraine

tel.: +380445263297

e-mail: tach2007@ukr.net

\section{Vira Govorukha, PhD, Researcher}

Zabolotny Institute of Microbiology and Virology of the NAS of Ukraine, Department of Extremophilic Microorganism Biology, room 224

Address: Zabolotny str., 154, Kyiv, 03143, Ukraine

tel.: +380445263297

e-mail: vera_govor@mail.ru

\section{Olesya Havryliuk, Student}

National Aviation University, Institute of Ecological Safety,

Department of Biotechnology, Master Program in "Microbiology"

Address: Kosmonavta Komarova str., 1, Kyiv, 03058, Ukraine

tel.: +380444067901

e-mail: gav_olesya@ukr.net 